\title{
The influence of a high-density sludge acid mine drainage (AMD) chemical treatment plant on water quality along the Blesbokspruit Wetland, South Africa
}

\author{
Mauro Lourenco ${ }^{1}$ and Chris Curtis ${ }^{2}$ \\ 'Department of Geography, Archaeology and Environmental Studies, University of the Witwatersrand, Johannesburg, South Africa \\ ${ }^{2}$ Department of Geography, Environmental Management and Energy Studies, University of Johannesburg, PO Box 524, \\ Auckland Park 2006, Johannesburg, South Africa
}

The Eastern Basin chemical acid mine drainage (AMD) treatment plant is one of the world's largest highdensity sludge (HDS) plants, and came into operation in August 2016. The plant is situated near the inoperative Grootvlei Mine in Springs, South Africa, and upstream of the Blesbokspruit Wetland, a former Ramsar Wetland of International Importance, now on the Montreux Record. Since being in operation it has had a major influence on surface water quality along the wetland area. The plant was constructed to mitigate the anticipated decant of AMD water from the abandoned Grootvlei Mine into the Blesbokspruit Wetland. Making use of the BACI (Before-After-Control-Impact) design, this study compares surface water quality of the Blesbokspruit upstream (control site) and downstream (impact site) of the treatment plant for 3-year periods before and after it came into operation. Quarterly water quality data (aluminium, ammonia, chloride, conductivity, dissolved oxygen, fluoride, iron, magnesium, manganese, nitrate, $\mathrm{pH}$, phosphate, sodium and sulphate) from 2013-2019 were used for 5 historical Rand Water monitoring sites along the Blesbokspruit. The current HDS treatment process has negatively influenced conductivity, chloride, magnesium, sodium and sulphate levels downstream. Since the commissioning of the treatment plant, the levels of these parameters have increased significantly. Notably, conductivity and sulphate have reached the management range defined as 'unacceptable' within the framework set out by the Blesbokspruit Forum (which is less stringent than the national guidelines for aquatic ecosystems), with potential impacts on salinization of the Vaal Barrage downstream. However, the significant reduction of iron, ammonia and phosphate concentrations downstream of the plant may be a combined beneficial effect of dilution by increased discharge from the plant and the wetland removing these contaminants. These results highlight the need for further research into possible secondary treatment and desalinisation mechanisms and the potential ecological and downstream water supply implications of increasing salinity within the area.

\section{CORRESPONDENCE}

Mauro Lourenco

\section{EMAIL}

mauro95cesar@gmail.com

\section{DATES}

Received: 3 April 2020

Accepted: 15 December 2020

\section{KEYWORDS}

water quality

$\mathrm{BACl}$

Ramsar

salinisation

Montreux Record

high-density sludge treatment Marievale

\section{COPYRIGHT}

() The Author(s)

Published under a Creative

Commons Attribution 4.0

International Licence

(CC BY 4.0)

\section{INTRODUCTION}

Acid mine drainage (AMD) is one of the most destructive forms of pollution in terms of water quality (Oberholster, 2010; McCarthy, 2011; Ambani and Annegarn, 2015). The process of AMD generation is well understood; through exposure of pyrite and other minerals by mining activities, water arising in or drained from coal and gold mines contains sulphuric acid and toxic heavy metals (Ochieng et al., 2010; McCarthy, 2011). If this water is left untreated, it can pose serious health risks to human communities, and cause major contamination in the natural environment (Ochieng et al., 2010; McCarthy, 2011). In South Africa, AMD is a broad geographic problem due to the numerous gold and coal mines that span the provinces of Gauteng, North West, Mpumalanga and Limpopo (McCarthy, 2011). Within Gauteng, the Witwatersrand gold fields span the Western, Central and Eastern Basins. Specifically, within the Witwatersrand Eastern Basin; Brakpan, Springs and Nigel are historic gold-mining towns (McCarthy, 2011).

Grootvlei Proprietary Mine in Springs was in operation from 1934 until 2010 and is located within the Blesbokspruit Wetland (Ambani and Annegarn, 2015). The mine is upstream of the Marievale Bird Sanctuary that lies within the southern half of the Blesbokspruit Wetland (DWS, 2017). The Blesbokspruit Wetland formed during the 1930 construction of road and pipeline embankments for the mining industry (UNEP-AEWA, 2020), and developed as a result of increased flow regimes brought about during the dewatering operations of the mine over many years (Roychoudhury and Starke, 2006; Ochieng et al., 2010). The Blesbokspruit Wetland was first accepted as a Ramsar Wetland of International Importance in 1986 due to the important biodiversity (locally migrant waterbirds and various notable mammals at Marievale Bird Sanctuary) it supported during the accreditation period (Ambani and Annegarn, 2015; Ramsar, 2020; UNEP-AEWA, 2020).

Grootvlei Mine started major pumping from Shaft 3 in 1995 but the resultant precipitation of red AMD sludge at the surface meant that the mine was ordered to stop by national government (Thorius, 2004). However, in 1996 the wetland was placed on the Montreux Record in response to this contamination (Ramsar, 2020). The Montreux Record is a register which lists potentially threatened or degraded Ramsar sites that no longer meet the Ramsar Convention standards, and the wetland remains on this register to the present day (Ramsar, 2020; UNEP-AEWA, 2020). Grootvlei Mine began pumping again in 1996 on condition that they treated underground water pumped to the surface through the use of a high-density sludge (HDS) process before discharge into the Blesbokspruit (De Wet and Sidu, 2013; 
Ambani and Annegarn, 2015). The HDS process is an active, abiotic (chemical) treatment designed to neutralise the acidic mine-water and allow for the precipitation and removal of heavy metals (Akcil and Koldas, 2006; Johnson and Hallberg, 2005). The original smaller HDS plant undoubtedly improved effluent quality while the mine was in operation; however, it produced water with high dissolved salt content that was discharged downstream (Thorius, 2004; Ambani and Annegarn, 2015).

After closure of the mine in 2010, both pumping and AMD treatment ceased and water quality temporarily improved in the Blesbokspruit (Ambani and Annegarn, 2015), but recharge of previously dewatered areas would ultimately lead to decant of AMD water at the surface. At Grootvlei, underground water during mining operations was found to have extremely high levels of sulphate (mean for 1999-2009 of $1585 \mathrm{mg} / \mathrm{L}$ ), with very high levels of manganese (mean during 1999-2009 of $3.6 \mathrm{mg} / \mathrm{L}$ ), total dissolved solids (TDS) (mean during 2003 of $2879 \mathrm{mg} / \mathrm{L}$ ), electrical conductivity (mean during 2003 of $321.8 \mathrm{mS} / \mathrm{m}$ ), iron (mean during 2003 of $135 \mathrm{mg} / \mathrm{L}$ ) and magnesium (mean during 2003 of $197 \mathrm{mg} / \mathrm{L}$ : Thorius, 2004; De Wet and Sidu, 2013). Defunct mines had the potential to decant underground AMD water at numerous locations across the Witwatersrand gold fields so national government took action to resolve the issues in the Western, Central and Eastern Basins (DWS, 2017). The TransCaledon Tunnel Authority (TCTA), an agency of the national Department of Water and Sanitation (DWS), was instructed to manage AMD within the three Witwatersrand basins (DWS 2017). The TCTA Eastern Basin AMD project is aimed at implementing the short-term (Phase One) solution in which the main objective is to stop the environmental critical levels being breached (DWS, 2017). The environmental critical level is the water level in mine voids at the critical location which needs to be maintained, and not allowed to rise, in order to prevent decant of AMD and protect the environment, including groundwater resources (DWA, 2012).

In August 2016, one of the world's largest HDS plants was commissioned to treat AMD for the Eastern Basin (DWS, 2017). The 1 billion ZAR plant has the capacity to pump $108 \mathrm{ML}$ of water per day to mitigate against the pollution of underground water sources (DWS, 2017). According to the DWS press release at the official launch of the plant in February 2017, the short- and long-term solutions to AMD are expected to cost 10-12 billion ZAR, which will be funded by the state, mining sector and water users (DWS, 2017). The short-term remediation used for the treatment of AMD water in the three basins of the Witwatersrand Gold Fields is neutralisation through HDS treatment and removal of the toxic metals that precipitate out of solution (McCarthy, 2011; DWS, 2017).
Although this treatment has its benefits, it does not solve the problem entirely. This process leads to increased salinity as well as promoting high concentrations of sulphate in the water (Van der Merwe and Lea, 2003; McCarthy, 2011; De Wet and Sidu, 2013). The secondary aim (Phase Two) would involve the potential use of desalination infrastructure to remove some of the soluble salts from the treated mine-water, thereby reducing the salt load to the catchments into which discharge will take place (Creamer, 2016).

The new Eastern Basin HDS AMD treatment plant is situated at Grootvlei Mine shaft no.3. This shaft has a depth of $1 \mathrm{~km}$ and three heavy-duty pumps ( $150 \mathrm{~m}$ deep) pump the AMD water out to the surface (Solomons, 2017). The first treatment at the new plant involves oxidation by aeration, where pyrite $\left(\mathrm{FeS}_{2}\right)$, oxygen $\left(\mathrm{O}_{2}\right)$ and water $\left(\mathrm{H}_{2} \mathrm{O}\right)$ produce iron (III) hydroxide $\left(\mathrm{Fe}(\mathrm{OH})_{3}\right)$ and sulphuric acid $\left(\mathrm{H}_{2} \mathrm{SO}_{4}\right)$. The AMD water is then transferred to a splitter box and is separated across three reactor circuits, which include pre-neutralisation with limestone $\left(\mathrm{CaCO}_{3}\right)$ or dolomite $\mathrm{CaMg}\left(\mathrm{CO}_{3}\right)_{2}$, and final neutralisation with slaked lime $\mathrm{Ca}(\mathrm{OH})_{2}$ and gypsum $\left(\mathrm{CaSO}_{4} \cdot 2 \mathrm{H}_{2} \mathrm{O}\right.$ : Solomons, 2017). Hence by-products include iron hydroxide $\left(\mathrm{Fe}(\mathrm{OH})_{3}\right)$, gypsum and magnesium sulphate $\left(\mathrm{MgSO}_{4}\right)$, some of which are removed in the sludge and some of which (especially magnesium) remain in solution (Aubé and Lee, 2015). The Blesbokspruit waters were already described as having high TDS, indicated by high electrical conductivity, in studies published before the new HDS AMD treatment plant came into operation, attributed to mining activity and the original HDS plant (Thorius, 2004; Ambani and Annegarn, 2015). This study sets out to provide an updated assessment of the surface water quality in the Blesbokspruit since the new Eastern Basin HDS AMD treatment plant came into operation in August 2016.

A powerful experimental design for detecting change in a system caused by a disturbance, which is known in advance, is the Before-After-Control-Impact design (BACI: Underwood, 1994; Millidine et al., 2015). A BACI study requires monitoring data for an anticipated impact site and a comparable control site (where no impact is expected), both before and after the disturbance occurs (Smith et al., 1993; Smith, 2014). The simple BACI design employed in this study to test two key hypotheses is shown schematically in Fig. 1. Prior to operation of the new HDS AMD water treatment plant (WTP) in August 2016 ('before' period), Sites 1 and 2 might be expected to show similar water quality, given the absence of any major point sources in the $6.5 \mathrm{~km}$ flow distance between them. Site 1, upstream of the new WTP, is effectively the control site, while Site 2 which is downstream of the new WTP discharge point is the impact site. Any changes in river water quality due to the commissioning of the WTP ('after' period) should be observable at Site 2 but not at Site 1.

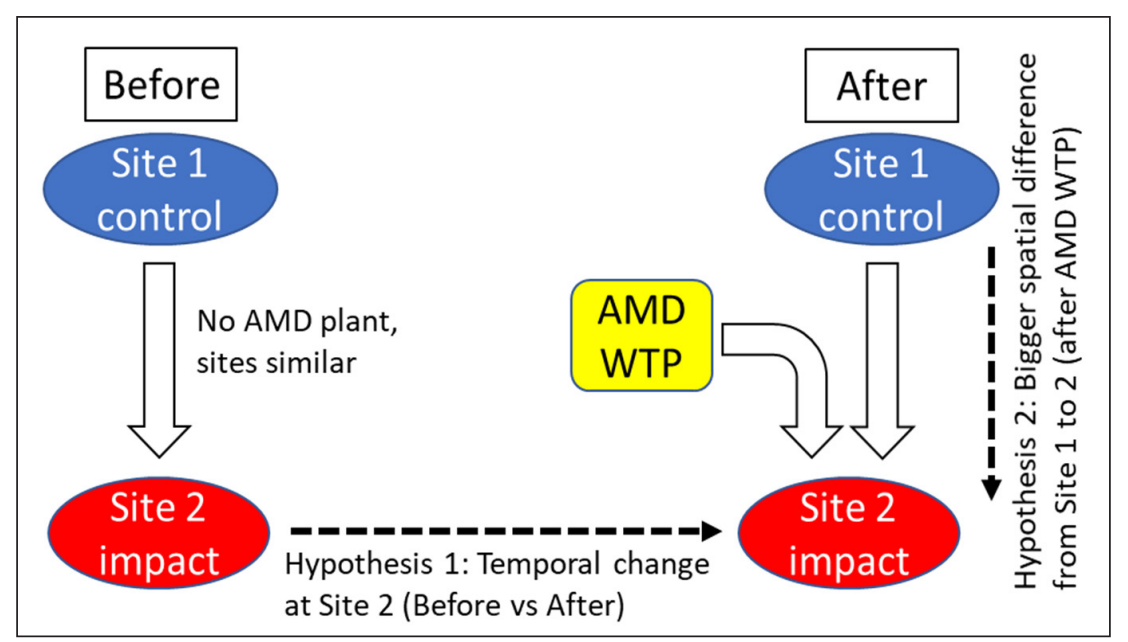

Figure 1. Schematic diagram of $\mathrm{BACl}$ design and associated hypotheses 
Two hypotheses were tested for this study:

1. Hypothesis 1 (temporal change, before vs after): Commissioning of the new HDS AMD WTP in August 2016 has a measurable/statistically significant impact on water quality at Impact Site 2 (downstream) but not at Control Site 1 (upstream);

2. Hypothesis 2 (spatial difference): There is a measurable/ statistically significant difference between Control Site 1 and Impact Site 2 with the new treatment plant in operation (after).

\section{METHODOLOGY}

The Blesbokspruit Wetland forms part of the Blesbokspruit catchment which falls within the former Upper Vaal Barrage Catchment Management Area (CMA) - now the Vaal CMA. Since 1975, Rand Water has closely monitored the area at 17 sites across the catchment (Ambani and Annegarn, 2015). For this study, quarterly monitoring records for 5 monitoring sites have been used from the start of 2013 to the end of 2019. These dates have been chosen to compare the surface water quality over 3 -year periods before and after the treatment plant came into operation. The five sites monitored by Rand Water which were used include: Site B5 at the Welgedacht inflow into the wetland (hereafter Site 1 - the control site), Site B16 at the Grootvlei Mine Train Bridge immediately downstream of the discharge point of the treatment plant (hereafter Site 2 - the impact site), Site B15 on the N17 Toll Road in Springs upstream of the Marievale Bird Sanctuary, Site B17 within the Marievale Bird Sanctuary and Site B11 at the R42 bridge near Nigel where the stream flows out of the Blesbokspruit Wetland area. The site locations and the treatment plant are shown in Fig. 2, which also illustrates the extent of the Blesbokspruit Wetland, slimes dams, adjacent towns, land use and the position of the Eastern Basin AMD treatment plant.

\section{Study site map}

Of the five historical Rand Water sites shown in Fig. 2, the two key sites for this study are Site 1 (B5) upstream and Site 2 (B16) immediately downstream of the Eastern Basin AMD treatment plant. The additional three sites have been included to assess the spatial extent of the chemical signature downstream and to identify whether there is any improvement in water quality due to the presence of the Blesbokspruit Wetland. For further details on each site see the Appendix or refer to Ambani and Annegarn (2015).

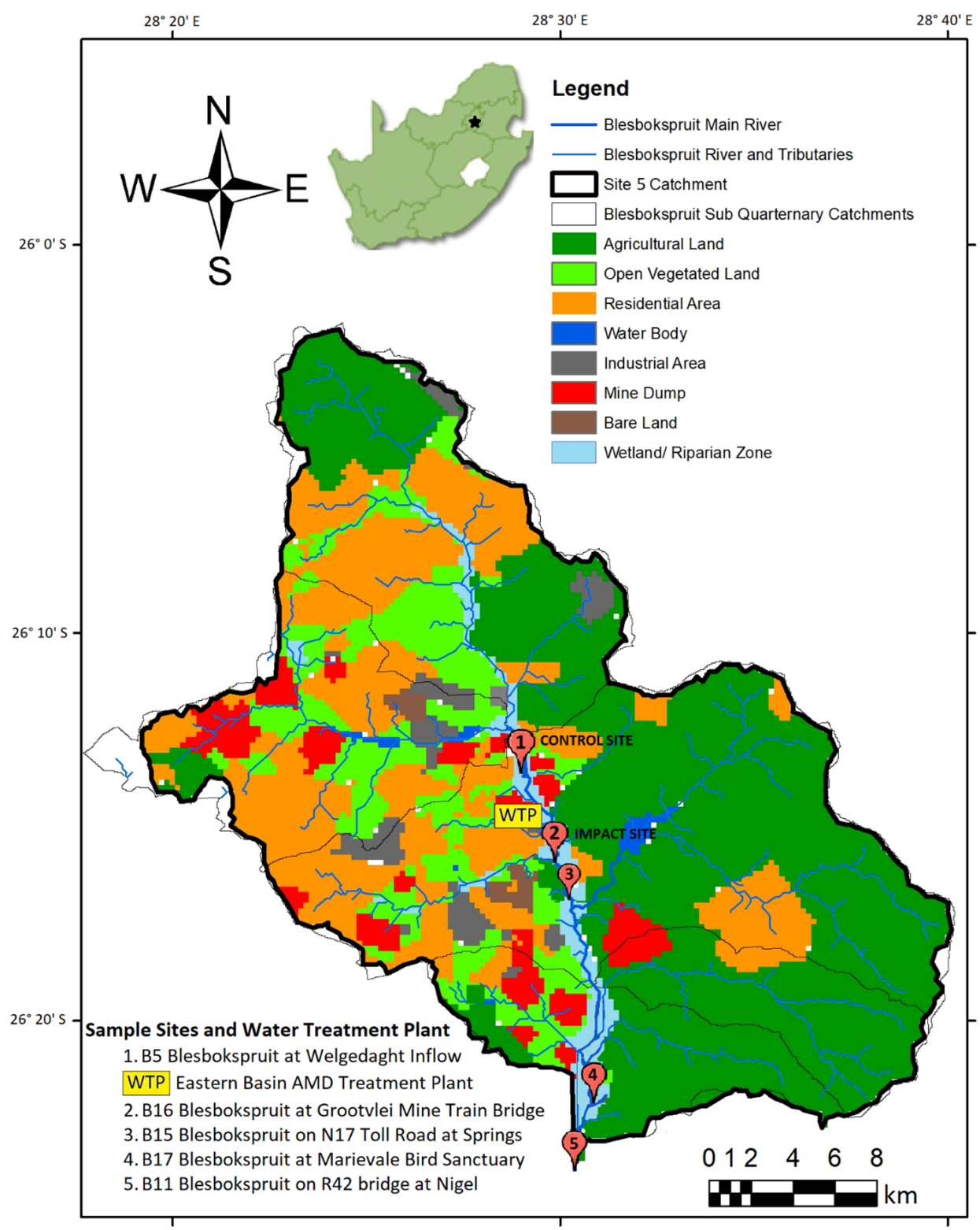

Figure 2. Catchment boundary of Site 5 (includes catchments of Sites 1,2,3 and 4) indicating land use and position of the AMD water treatment plant (WTP); river flows from north to south 
Table 1. Instream water quality guidelines for the Blesbokspruit catchment (effective June 2003)

\begin{tabular}{lccccc}
\hline Water quality variables & $\begin{array}{c}\text { Measurement } \\
\text { units }\end{array}$ & $\begin{array}{c}\text { Ideal catchment } \\
\text { background }\end{array}$ & $\begin{array}{c}\text { Acceptable } \\
\text { management target }\end{array}$ & $\begin{array}{c}\text { Tolerable interim } \\
\text { target }\end{array}$ & Unacceptable \\
\hline Aluminium & $\mathrm{mg} / \mathrm{L}$ & $<0.1$ & $<0.3$ & $0.3-0.5$ & $>0.5$ \\
Ammonia & $\mathrm{mg} / \mathrm{L}$ & $0.1-1.5$ & $1.5-5$ & $>5$ \\
Chloride & $\mathrm{mg} / \mathrm{L}$ & $<8$ & $80-150$ & $150-200$ & $>200$ \\
Conductivity & $\mathrm{mS} / \mathrm{m}$ & $<45$ & $45-70$ & $70-120$ & $>120$ \\
DO & $\mathrm{mg} / \mathrm{L}$ & & $>6.0$ & $5.0-6.0$ & $<5.0$ \\
Fluoride & $\mathrm{mg} / \mathrm{L}$ & $<0.19$ & $0.19-0.70$ & $0.70-1.0$ & $>1.0$ \\
Iron & $\mathrm{mg} / \mathrm{L}$ & $<0.1$ & $0.1-0.5$ & $0.5-1.0$ & $>1.0$ \\
Magnesium & $\mathrm{mg} / \mathrm{L}$ & $<8$ & $8-30$ & $30-70$ & $>70$ \\
Manganese & $\mathrm{mg} / \mathrm{L}$ & $<0.2$ & $0.2-0.5$ & $0.5-1.0$ & $>1.0$ \\
Nitrate & $\mathrm{mg} / \mathrm{L}$ & $<0.5$ & $0.5-3.0$ & $3.0-6.0$ & $>6.0$ \\
pH & $\mathrm{pH}$ units & $6.5-8.5$ & & & $<6.5 ;>8.5$ \\
Phosphate & $\mathrm{mg} / \mathrm{L}$ & $<0.2$ & $0.2-0.4$ & $0.4-0.6$ & $>0.6$ \\
Sodium & $\mathrm{mg} / \mathrm{L}$ & $<70$ & $70-100$ & $100-150$ & $>150$ \\
Sulphate & $\mathrm{mg} / \mathrm{L}$ & $<150$ & $150-300$ & $300-500$ & $>500$ \\
\hline
\end{tabular}

Available online from The Reservoir Website, http://www.reservoir.co.za/forums/vaalbarrage/blesbok_forum/blesbok_documents/BF_WQGuidelines.pdf.

The water quality guidelines shown in Table 1 are used as an indication of the raw instream water quality specifically for the Blesbokspruit catchment. Water quality parameters are described as ideal, acceptable, tolerable and unacceptable, and are unique to the Blesbokspruit management targets set out by the Blesbokspruit Forum (Reservoir, 2018). However, the guidelines are limited in that they are far less strict than those of the standard water quality guidelines set out by the Department of Water and Sanitation for aquatic ecosystems (DWAF, 1996a; McKay et al., 2018), which were modified to account for the mining and industrial processes occurring along the Blesbokspruit (McKay et al., 2018). The Blesbokspruit can therefore be described as a hard-working river, whereby the ecosystem services provided by the stream help meet the reserve, defined as the quality and quantity of water required to meet basic human needs and to protect aquatic ecosystems (Claassen, 2010; McKay et al., 2018).

The Blesbokspruit is a tributary to the Vaal system which provides drinking water to the people of Gauteng (Roychoudhury and Starke, 2006), and has previously been described as having increased salinity due to inputs by the Blesbokspruit and Klip River (McCarthy, 2011). Considering that the Blesbokspruit is not managed to be used directly for domestic drinking purposes, the raw water quality guidelines set out by the Blesbokspruit Forum are used for this study. The Blesbokspruit Forum promotes the aims of the National Water Act (Act 36 of 1998; RSA, 1998) and the role players include government departments, non-governmental organisations, mines, industries, other water users and the general population (Reservoir, 2018). Rand Water manually collects water samples from each site monthly, with the quarterly water quality results representing an average of the monthly water quality data over that period. The quarterly results are uploaded to The Reservoir website after the analysis is completed (Reservoir, 2020). Standard methods and protocols are followed by Rand Water technicians during the sampling procedure, preservation, transportation and analysis of the water samples (Rand Water, 2012). The data from Rand Water comprised quarterly surface water quality parameters from the start of 2013 to the end of 2019: aluminium, ammonia, chloride, conductivity, dissolved oxygen, fluoride, iron, magnesium, manganese, nitrate, $\mathrm{pH}$, phosphate, sodium and sulphate. Rand Water Analytical Services is fully accredited by the South African National Accreditation System (SANAS) which maintain international analytical standards (Rand Water, 2020).

\section{Statistical methods}

The complete dataset obtained from Rand Water had no missing values and was not altered in any way; the data were statistically analysed using XLSTAT software (Addinsoft, 2020). The BACI design makes use of a standard t-test for comparison of means or the corresponding non-parametric equivalent (Smith et al., 1993). Statistical analysis determined that data were not normally distributed using the Jarque-Bera, Shapiro-Wilk and Doornik Chi-Square normality tests. Therefore, non-parametric tests were conducted on the data, assuming statistically significant differences where $p<0.05$.

The BACI design made use of 4 sets of analyses to test against the 2 hypotheses for this study. Tests 1 and 2 tested for temporal change at Control Site 1 (Test 1) and Impact Site 2 (Test 2) for 3-year periods before and after the treatment plant came into operation (Hypothesis 1), using the Wilcoxon signed-rank 2-tailed test. Tests 3 and 4 tested for spatial differences between Control Site 1 and Impact Site 2, both before (Test 3) and after (Test 4) the treatment plant came into operation (Hypothesis 2), using the Mann-Whitney 2-tailed test.

\section{RESULTS}

Tables 2 and 3 are a summary of the results of tests for Hypothesis 1 (Tests 1 and 2) and Hypothesis 2 (Tests 3 and 4), respectively.

Comparison of means at Control Site 1 for the 3 -year periods before and after commissioning of the plant shows a significant difference in only 2 of the 14 water quality parameters (aluminium significantly increased and dissolved oxygen significantly decreased), which cannot be attributed to the treatment plant. At the control site there was no change in the Rand Water quality targets for any of the water quality variables through time. In contrast, for Impact Site 2 commissioning of the plant shows a significant increase in aluminium, chloride, conductivity, magnesium, sodium, and sulphate. For conductivity, the increase results in deterioration to an unacceptable water quality while magnesium, sodium and sulphate deteriorate to tolerable (interim) target ranges. Conversely, both ammonia and phosphate show a significant decline in mean concentrations following the commissioning of the plant, with ammonia improving from tolerable to acceptable target ranges while phosphate remains unacceptable despite almost halving in concentration at Impact Site 2. 
Table 2. Summary of Hypothesis 1

\begin{tabular}{|c|c|c|c|c|c|c|c|c|c|c|}
\hline \multicolumn{6}{|c|}{ Test 1. Control Site 1 before WTP vs after WTP } & \multicolumn{5}{|c|}{ Test 2. Impact Site 2 before WTP vs after WTP } \\
\hline Water quality variable & $p$-value & $\begin{array}{c}\text { Mean } \\
\text { before } \\
\text { WTP }\end{array}$ & $\begin{array}{c}\text { Mean } \\
\text { after } \\
\text { WTP }\end{array}$ & $\begin{array}{l}\text { Ratio: } \\
\text { mean }\end{array}$ & $\begin{array}{c}\% \text { change: } \\
\text { mean }\end{array}$ & $p$-value & $\begin{array}{c}\text { Mean } \\
\text { before } \\
\text { WTP }\end{array}$ & $\begin{array}{l}\text { Mean } \\
\text { after } \\
\text { WTP }\end{array}$ & $\begin{array}{l}\text { Ratio: } \\
\text { mean }\end{array}$ & $\begin{array}{c}\text { \% change: } \\
\text { mean }\end{array}$ \\
\hline Aluminium (mg/L) & 0.026 & 0.03 & 0.07 & 2.21 & 121.43 & 0.002 & 0.02 & 0.04 & 2.41 & 140.91 \\
\hline Ammonia (mg/L) & 0.391 & 2.70 & 2.00 & 0.74 & -25.99 & 0.003 & 2.17 & 0.63 & 0.29 & -71.06 \\
\hline Chloride (mg/L) & 0.135 & 59.00 & 70.29 & 1.19 & 19.13 & 0.003 & 64.14 & 83.71 & 1.31 & 30.51 \\
\hline Conductivity (mS/m) & 0.683 & 74.14 & 71.36 & 0.96 & -3.76 & 0.000 & 79.50 & 130.29 & 1.64 & 63.88 \\
\hline Dissolved oxygen (mg/L) & 0.024 & 3.06 & 1.92 & 0.63 & -37.30 & 0.490 & 3.94 & 3.28 & 0.83 & -16.85 \\
\hline Fluoride (mg/L) & 0.706 & 0.31 & 0.40 & 1.29 & 29.06 & 0.232 & 0.33 & 0.65 & 2.00 & 100.00 \\
\hline Iron (mg/L) & 0.625 & 0.20 & 0.25 & 1.22 & 21.63 & 0.777 & 0.09 & 0.09 & 1.03 & 3.17 \\
\hline Magnesium (mg/L) & 0.161 & 15.21 & 16.93 & 1.11 & 11.27 & 0.001 & 17.29 & 37.07 & 2.14 & 114.46 \\
\hline Manganese (mg/L) & 0.861 & 0.31 & 0.29 & 0.93 & -6.76 & 0.078 & 0.45 & 0.24 & 0.53 & -47.32 \\
\hline Nitrate $(\mathrm{mg} / \mathrm{L})$ & 0.626 & 0.98 & 1.09 & 1.12 & 11.57 & 0.221 & 0.91 & 0.99 & 1.09 & 8.91 \\
\hline $\mathrm{pH}$ (pH units) & 0.764 & 7.42 & 7.41 & 1.00 & -0.19 & 0.913 & 7.54 & 7.55 & 1.00 & 0.19 \\
\hline Phosphate (mg/L) & 0.102 & 0.65 & 1.05 & 1.61 & 60.79 & 0.026 & 1.17 & 0.61 & 0.52 & -47.62 \\
\hline Sodium (mg/L) & 0.660 & 64.00 & 66.79 & 1.04 & 4.35 & 0.006 & 68.50 & 102.79 & 1.50 & 50.05 \\
\hline Sulphate (mg/L) & 0.233 & 103.29 & 124.29 & 1.20 & 20.33 & 0.000 & 110.36 & 399.29 & 3.62 & 261.81 \\
\hline
\end{tabular}

Significant differences $(p<0.05)$ are in bold; mean values are colour coded according to Blesbokspruit Forum water quality guidelines (see Table 1). The proportional change in mean value (ratio and \% change) is shaded in pink for an increase and green for a decrease.

Table 3. Summary of Hypothesis 2

\begin{tabular}{|c|c|c|c|c|c|c|c|c|c|c|}
\hline \multicolumn{6}{|c|}{ Test 3. Control Site 1 vs Impact Site 2 before WTP commissioned } & \multicolumn{5}{|c|}{$\begin{array}{l}\text { Test 4. Control Site } 1 \text { vs Impact Site } 2 \text { after WTP } \\
\text { commissioned }\end{array}$} \\
\hline Water quality variable & p-value & $\begin{array}{l}\text { Mean } \\
\text { Control } \\
\text { Site } 1\end{array}$ & $\begin{array}{l}\text { Mean } \\
\text { Impact } \\
\text { Site } 2\end{array}$ & $\begin{array}{l}\text { Ratio: } \\
\text { mean }\end{array}$ & $\begin{array}{l}\text { \% change: } \\
\text { mean }\end{array}$ & $p$-value & $\begin{array}{c}\text { Mean } \\
\text { Control } \\
\text { Site } 1\end{array}$ & $\begin{array}{l}\text { Mean } \\
\text { Impact } \\
\text { Site } 2\end{array}$ & $\begin{array}{l}\text { Ratio: } \\
\text { mean }\end{array}$ & $\begin{array}{l}\text { \% change: } \\
\text { mean }\end{array}$ \\
\hline Aluminium (mg/L) & 0.166 & 0.03 & 0.02 & 0.52 & -47.62 & 0.002 & 0.07 & 0.04 & 0.57 & -43.01 \\
\hline Ammonia (mg/L) & 0.642 & 2.70 & 2.17 & 0.80 & -19.63 & 0.000 & 2.00 & 0.63 & 0.31 & -68.57 \\
\hline Chloride (mg/L) & 0.250 & 59.00 & 64.14 & 1.09 & 8.72 & 0.016 & 70.29 & 83.71 & 1.19 & 19.11 \\
\hline Conductivity (mS/m) & 0.146 & 74.14 & 79.50 & 1.07 & 7.23 & 0.000 & 71.36 & 130.29 & 1.83 & 82.58 \\
\hline Dissolved oxygen (mg/L) & 0.242 & 3.06 & 3.94 & 1.29 & 28.67 & 0.034 & 1.92 & 3.28 & 1.71 & 70.63 \\
\hline Fluoride (mg/L) & 0.278 & 0.31 & 0.33 & 1.04 & 4.35 & 0.270 & 0.40 & 0.65 & 1.62 & 61.70 \\
\hline Iron (mg/L) & 0.199 & 0.20 & 0.09 & 0.45 & -55.32 & 0.001 & 0.25 & 0.09 & 0.38 & -62.10 \\
\hline Magnesium (mg/L) & 0.044 & 15.21 & 17.29 & 1.14 & 13.62 & 0.000 & 16.93 & 37.07 & 2.19 & 118.99 \\
\hline Manganese (mg/L) & 0.334 & 0.31 & 0.45 & 1.47 & 46.85 & 0.395 & 0.29 & 0.24 & 0.83 & $-17.03 \%$ \\
\hline Nitrate (mg/L) & 0.937 & 0.98 & 0.91 & 0.93 & -7.17 & 0.612 & 1.09 & 0.99 & 0.91 & -9.38 \\
\hline $\mathrm{pH}$ (pH units) & 0.066 & 7.42 & 7.54 & 1.02 & 1.54 & 0.131 & 7.41 & 7.55 & 1.02 & 1.93 \\
\hline Phosphate (mg/L) & 0.016 & 0.65 & 1.17 & 1.80 & 79.63 & 0.043 & 1.05 & 0.61 & 0.59 & -41.49 \\
\hline Sodium (mg/L) & 0.490 & 64.00 & 68.50 & 1.07 & 7.03 & 0.001 & 66.79 & 102.79 & 1.54 & 53.90 \\
\hline Sulphate (mg/L) & 0.407 & 103.29 & 110.36 & 1.07 & 6.85 & 0.000 & 124.29 & 399.29 & 3.21 & 221.26 \\
\hline
\end{tabular}

Significant differences $(p<0.05)$ are in bold; mean values are colour coded according to Blesbokspruit Forum water quality guidelines (see Table 1). The proportional change in mean value (ratio and \%) is shaded in pink for an increase and green for a decrease.

For the period before the WTP was commissioned, only magnesium and phosphate were found to show significant differences, both higher at Impact Site 2. For the 3-year period after commissioning of the WTP, there are significant differences for 10 of the 14 water quality parameters between Control Site 1 and Impact Site 2. Significantly higher levels of chloride, conductivity, dissolved oxygen, magnesium, sodium and sulphate are found at the impact site, parameters that were also found to increase following commissioning of the plant at the impact site. Significantly lower concentrations of aluminium, ammonia, iron and phosphate are found at the impact site for the period after commissioning of the plant. Magnesium was only slightly higher at the impact site before commissioning but more than double after. Notably for phosphate, concentrations were higher at the impact site before commissioning, which does suggest some local inputs, but were much lower than the control site after commissioning, indicating a dilution effect, since concentrations at the control site had increased in this later period. 


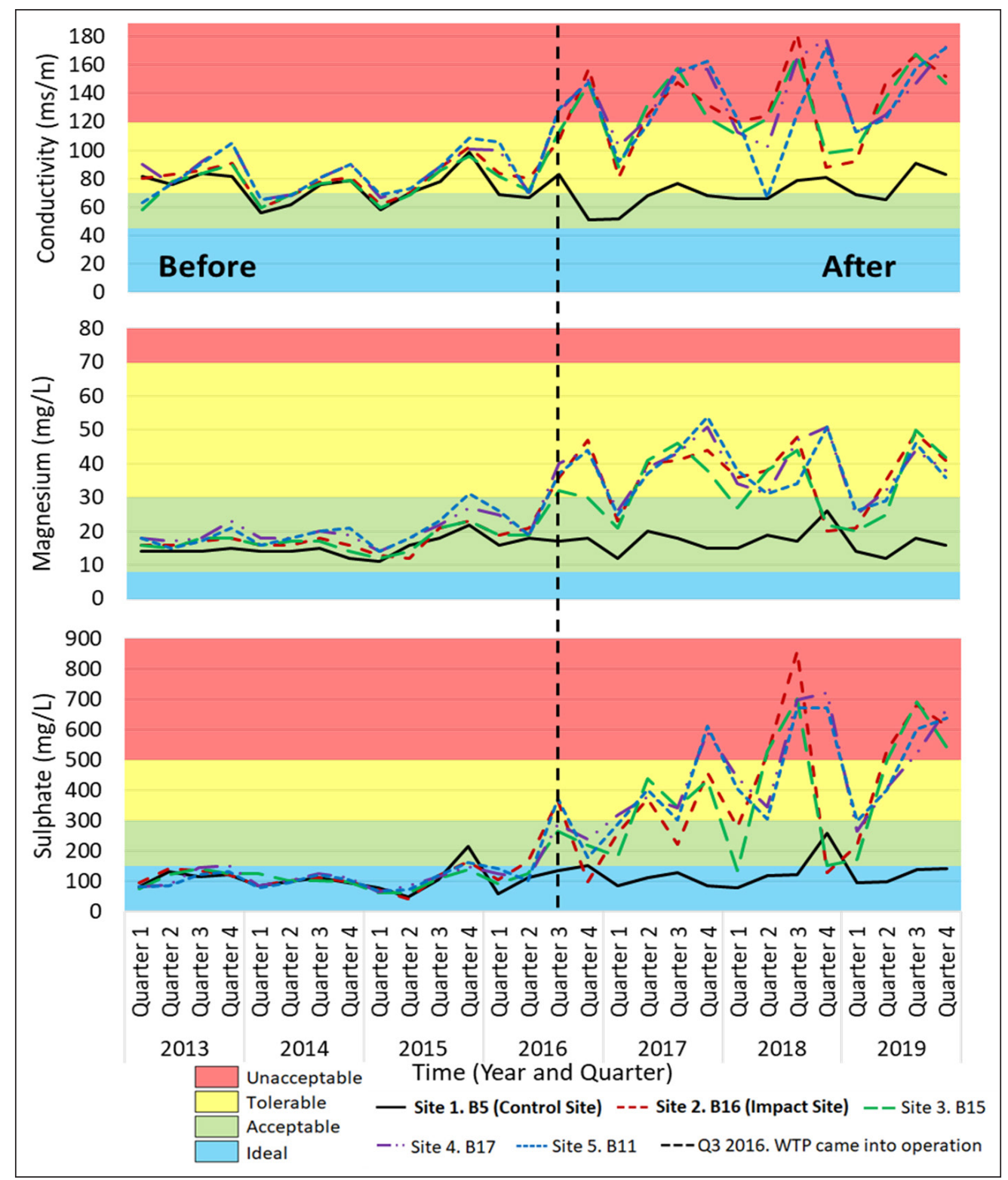

Figure 3. Rand Water time-series charts for conductivity, sulphate and magnesium for the period 1 Jan 2013 to 31 Dec 2019. The colours on the charts correspond to the Blesbokspruit Forum water quality guidelines for each specific variable and the dashed black line indicates the quarter in which the treatment plant came into operation (Q3 2016).

\section{Time-series charts for Rand Water data}

Rand Water time-series charts were generated for conductivity, sulphate and magnesium for the five study sites. (Charts for the remaining water quality parameters are shown in the Appendix.)

Figure 3 shows the trend in water quality for 3 water quality variables. There are 5 main trends that come out of the data summary tables (Tables 2 and 3) and time-series analysis (Fig. 3).

1. All the sites have very similar seasonal patterns and mean values for the 3 -year period before the commissioning of the treatment plant. Differences (if any) between individual sites are smaller before the treatment plant came into operation vs after the treatment plant came into operation.

2. During the period after commissioning of the treatment plant, significant differences appear between the control site, Site 1, and the impact site, Site 2, with significant increases in chloride, conductivity, dissolved oxygen, magnesium, sodium and sulphate, and significant decreases in aluminium, ammonia, iron and phosphate. All downstream sites diverge from upstream Control Site 1 after opening of the plant, while Site 1 shows no apparent change.
3. There is little evidence of differences between Impact Site 2 and the remaining downstream Sites 3, 4 and 5 as the river moves through the wetland.

4. Notably, both conductivity and sulphate have reached unacceptable management target levels since the treatment plant came into operation.

5. All changes downstream are consistent with what is known about the effluent from the plant and predictions in the scoping study (Digby Wells and Associates, 2012). Effluent quality data from the plant for the final quarter of 2019 indicate pumped volumes of 63-70 ML/day with mean concentrations of $92 \mathrm{mg} / \mathrm{L}$ magnesium, $1166 \mathrm{mg} / \mathrm{L}$ sulphate and conductivity of $240 \mathrm{mS} / \mathrm{m}$ (Reservoir, 2020). These values are higher than upstream concentrations for the same period by factors of 5.8, 8.2 and 2.9, respectively.

These concentrations and flow rates can be used to calculate the relative flow contribution of the effluent and potential downstream fluxes as described below.

If it is assumed that proportional increases in concentrations of conservative ions (i.e., magnesium and sulphate) reflect a simple 
mixing of flows (i.e. no losses through precipitation as solids and no other inputs) between those arriving from the control site upstream and the effluent discharge from the plant, then the relative flow contribution of the effluent may be estimated as:

\section{Floweffluent $/$ Flow ${ }_{\text {control }}=$}

(concimpact - conc control) / (conceffluent - concimpact)

Magnesium concentrations indicate that effluent flows are 0.37 times the upstream contribution, while sulphate indicates a smaller ratio of 0.26 , i.e., the mean of these ratios indicates that effluent flows are approximately one third (0.32) of those arriving from upstream. With pumped effluent volumes of $70 \mathrm{ML} /$ day this suggests an upstream input of approx. $218.8 \mathrm{ML} /$ day and total downstream flow of $288.8 \mathrm{ML} /$ day. These concentrations and flows may be used to estimate fluxes; effluent inputs of 6.44 $\mathrm{t} /$ day of magnesium and $81.62 \mathrm{t} /$ day of sulphate result in total downstream transport of $10.71 \mathrm{t}$ /day of magnesium and 115.32 t/day of sulphate.

\section{DISCUSSION}

Analysis of the Rand Water data has confirmed that since commissioning of the WTP, several key water quality parameters have changed significantly at the downstream Impact Site 2 (Hypothesis 1), with significant differences from the upstream Control Site 1 (Hypothesis 2), clearly showing changes in water quality of the Blesbokspruit that may be attributed to the operation of the new AMD treatment plant.

\section{Deterioration in water quality}

The Blesbokspruit waters were described as being highly conductive before the AMD treatment plant came into operation (Ambani and Annegarn, 2015). Through the use of the BACI design, the results of this study indicate that the AMD treatment plant is increasing conductivity levels within an existing, high TDS environment. It is reasonable to assume that Phase One of the AMD treatment plant (HDS treatment) has beneficial impacts in treating heavy metals from underground AMD water and maintaining groundwater below the environmental critical level. However, the HDS processes used by the plant are not improving water quality downstream, especially with regards to TDS (conductivity and specifically sulphate). Conductivity and sulphate levels have increased dramatically since the commissioning of the new AMD treatment plant and are of high concern for the majority of the Blesbokspruit Wetland. Conductivity and sulphate lie within the tolerable to unacceptable management target levels which have high potential to be damaging to the environment.

The earlier study of Ambani and Annegarn (2015) investigated the improvements in water quality at downstream sites following the cessation of pumping from the Grootvlei Mine when it closed at the end of 2010. They found that mean sulphate concentrations during mining operations (2000-2010) at Site 1 (B5), of $114 \mathrm{mg} / \mathrm{L}$, increased greatly below the discharge point to $510 \mathrm{mg} / \mathrm{L}$ at Site 2 (B16) and $496 \mathrm{mg} / \mathrm{L}$ at Site 5 (B11). Following cessation of pumping, during 2011 the mean sulphate upstream at Site 1 was very similar $(106 \mathrm{mg} / \mathrm{L})$ while downstream sites had only slightly elevated sulphate (137 and $163 \mathrm{mg} / \mathrm{L}$ at Sites 2 and 5, respectively). The current study shows that the commissioning of the treatment plant has resulted in downstream sulphate concentrations increasing sharply to an annual mean of $399 \mathrm{mg} / \mathrm{L}$ in the downstream site, levels not seen since 2007 (Ambani and Annegarn, 2015). In fact, during the past 3 years of pumping from the active mine (20082010), downstream sulphate levels were lower than they are at present with the new treatment plant in operation.

For magnesium, Ambani and Annegarn (2015) found mean concentrations of $17 \mathrm{mg} / \mathrm{L}$ at Site 1 upstream increased to $54 \mathrm{mg} / \mathrm{L}$ at Sites 2 and 5 downstream during the pumping period of 2000-2010. After cessation of pumping, mean concentrations for 2011 were 16, 19 and $24 \mathrm{mg} / \mathrm{L}$ at Sites 1, 2 and 5, respectively. The current study shows that while magnesium at Site 1 has changed little from the earlier study ( $17 \mathrm{mg} / \mathrm{L})$, at Site 2 the mean concentration during 2017-2019 increased from 17 to $37 \mathrm{mg} / \mathrm{L}$, similar to the 2010 value during the final year of pumping from the mine. A similar pattern was also observed for sodium, in that concentrations have increased towards the levels observed during mining. It is well recognised that magnesium and sodium may not precipitate out during HDS treatment, while calcium salts are also more soluble than most heavy metal hydroxides (Aubé and Lee, 2015).

\section{Potential downstream impacts}

The Blesbokspruit was accepted as a Ramsar Wetland of International Importance in 1986 and by 1996 the wetland was placed on the Montreux record, due to multiple stressors that persist to the present day with potential ecological impacts. Increasing TDS and changed flow regimes have previously been linked to a decline in aquatic biodiversity and encroachment of reed species into former open water areas (Thorius, 2004; McKay et al., 2018). Changes in TDS concentration have been found to affect individual aquatic species adaptations, community structure and microbial and ecological processes such as metabolic rates and nutrient cycling (DWAF, 1996a). The potential long-term impacts of the major increase in TDS observed in the present study, on more sensitive organisms that are adapted to freshwater, lower salinity environments, are unknown and merit further study.

Deteriorating water quality also has implications for human activities downstream which make use of the Blesbokspruit. Pilsen et al. (2000) reported that Grootvlei and the former Western Areas Gold Mine (WAGM) were contributing $26 \%$ of the salt load entering the Vaal Barrage from point-source discharges in 2000 and stressed the importance of management/treatment interventions to reduce this salt load. Flow at Grootvlei Mine prior to 2000 discharged $130 \mathrm{ML} /$ day downstream into the Vaal barrage, with TDS concentrations of $4156 \mathrm{mg} / \mathrm{L}$, magnesium concentrations of $117 \mathrm{mg} / \mathrm{L}$ and sulphate concentrations of $2085 \mathrm{mg} / \mathrm{L}$ (Pilsen et al., 2000). Fluxes calculated from these concentrations are $15.21 \mathrm{t} /$ day magnesium and $271.05 \mathrm{t} /$ day sulphate from mine-water effluent discharges alone, not accounting for upstream concentrations and flows. By comparison, effluent inputs from the new treatment plant during the last quarter of 2019 are $6.44 \mathrm{t} /$ day of magnesium and $81.62 \mathrm{t}$ /day of sulphate, which are much smaller than those reported in the earlier study of Pilsen et al. (2000), presumably reflecting greater pumping rates and lower treatment efficiency in the former HDS plant, or declining concentrations in the mine-water source to the present day. Although these effluent concentrations and fluxes have improved since mining, increased salinity remains an issue.

The increased salinity within the Vaal was previously documented by McCarthy (2011) and showed that the salinity of the Vaal River more than doubled between the Vaal Dam and the Vaal Barrage as a result of inflow of water from the Klip River and the Blesbokspruit. The Eastern Basin treatment plant may prove to exacerbate salinity in the Vaal which has been a concern since 2000, well before the commissioning of the new plant. Sulphate and magnesium levels remain below $1000 \mathrm{mg} / \mathrm{L}$ and $500 \mathrm{mg} / \mathrm{L}$, respectively, which is acceptable for livestock watering (DWAF, 1996b). However, conductivity levels should be maintained below $40 \mathrm{mS} / \mathrm{m}$ (DWAF, 1996c) for irrigation use and this has been exceeded. The implications of the increasing salinity for the Blesbokspruit will continue to persist without a secondary phase of treatment or repurposing of the treated mine-water effluents. 


\section{Improvements in water quality}

Certain water quality parameters have improved significantly since the treatment plant came into operation. Iron was consistently lower at sites downstream of Site 1 both before and after commissioning of the plant, but this difference was only significant afterwards. The nutrients ammonia and phosphate also show a statistically significant reduction in concentrations at the impact site after commissioning. This reduction was unexpected and is suggested to result from dilution of upstream sources due to increased flow caused by the AMD treatment plant discharge of low nutrient waters downstream. For nitrate, ammonia and phosphate the lowest concentrations are generally found at Site 5 furthest downstream, indicating an additional role of the wetland in attenuation of instream nutrient concentrations.

The time-series charts demonstrate that for conductivity, sulphate and magnesium the greater Blesbokspruit Wetland and the Marievale Wetland have a very minor influence on improving water quality within the area. The wetlands do appear to reduce nutrient levels, but the surface water quality in this study area is mainly influenced by what is occurring upstream of the wetlands at the Eastern Basin AMD treatment plant.

\section{Requirement for secondary treatment}

The HDS system itself is a highly effective and economical method used throughout the world in treating AMD water from mining and other industrial waste (Murdock et al., 1994; Aubé and Zinck, 1999). However, studies regarding HDS treatment have tended to evaluate the treatment itself without focusing on downstream discharges and potential environmental impacts (Murdock et al., 1994). In terms of the present study, the application of HDS treatment and resultant increase in salinity and sulphate in discharged effluents was expected in the short term, as documented in earlier studies (Van der Merwe and Lea, 2003; McCarthy, 2011; De Wet and Sidu, 2013). Some South African mines have already established additional secondary treatment processes to existing HDS infrastructure to treat AMD discharges to a more potable, industrial or agricultural standard (Akcil and Koldas, 2006). The GYP-CIX process, which uses cation and anion exchange resins to de-ionise solutions was implemented at the Western Areas Gold Mine; this process has both high water and economic recovery (Akcil and Koldas, 2006). At Optimum Mine in Mpumalanga, reverse osmosis was used to treat mine-impacted water from an open-pit coal mine and convert it into a large potable water supply for communities in the water-stressed mining area (Cogho and Van Niekerk, 2009; Cogho, 2012).The imperative for further treatment of AMD for alternative uses is explicitly acknowledged in the South African National Water and Sanitation Master Plan, which states that treated AMD will need to make a significant contribution to South Africa's water mix by 2040 (DWS 2018, p. 12).

The results of the current study have highlighted the need for further treatment and desalinisation mechanisms to address the salinity problem within the study area, an issue that was raised even during mining operations (Pilson et al., 2000; Van der Merwe and Lea, 2003). This issue has yet to be tackled and the conditions of the past along the Blesbokspruit have worsened under the current treatment (Phase One). Hence the planned long-term (Phase Two) solution involving the use of desalination infrastructure for improved water quality stated by DWS during the treatment plant launch in 2017 should be implemented as soon as possible.

\section{CONCLUSIONS}

This study set out to provide an updated assessment of the surface water quality in the Blesbokspruit since the Eastern Basin AMD treatment plant came into operation in August 2016, employing a BACI methodology. Two key hypotheses were tested and supported by the analyses presented here. The first hypothesis that temporal changes in water quality would be found at the Impact Site 2 downstream of the treatment plant after commissioning, but not at the upstream Control Site 1, was confirmed by statistically significant increases in chloride, conductivity, dissolved oxygen, magnesium, sodium and sulphate at Site 2, but not at Site 1 (Table 2, Fig. 3). Both sites showed significant increases in aluminium, but the increase at Site 1 indicates that this is due to upstream sources other than the treatment plant, which demonstrates the power of the BACI design. Site 2 also showed significant decreases in ammonia and phosphate which were not found at Site 1, suggesting that the treated effluent discharged into the Blesbokspruit is diluting nutrient inputs from upstream, probably originating from wastewater treatment works. This was an unexpected result which demonstrates some beneficial effects on water quality of the effluent discharge from the AMD treatment plant.

The second hypothesis tested was whether there would be significant differences in water quality at the control site, Site 1, and the impact site, Site 2, after commissioning, which would not be apparent before the treatment plant started operations. This hypothesis was also confirmed, with significantly greater concentrations of chloride, magnesium, sodium and sulphate and higher conductivity found at Site 2 than at Site 1 after commissioning of the plant. None of these differences between sites were apparent before the plant started operations, except that magnesium was slightly, but significantly, higher at Site 2 in the earlier period; however, the difference was greatly amplified by the discharge from the plant after commissioning. The lack of difference between any other variables between the two sites before the plant became operational indicates that Site 1 was an effective choice of control site for the BACI study.

The negative influences on water quality caused by the treatment plant are most notable for conductivity and sulphate, which have declined to unacceptable and tolerable (interim) management target levels, respectively, at downstream sites, as a result of the discharge of treated water from the treatment plant. These increases are due to high levels of TDS and especially sulphate in the discharge water released by the treatment plant.

The commissioning of the AMD treatment plant may have been essential to maintain groundwater levels below the environmental critical level for the Eastern Basin and avoid unregulated decant of raw AMD into the Blesbokspruit. Attention now needs to be given to the potential implementation of Phase Two (desalination) treatment to improve water quality from the treatment plant downstream, or to find alternative uses for the current treated effluent. Treated AMD water could have a critical role in securing water supply for Gauteng in the context of increasing demand, climate change and declining quality of surface waters within the region (GCRO, 2019); the imperative stated in the National Water and Sanitation Master Plan (DWS, 2018) for re-use of treated AMD needs to be put into action as soon as possible.

\section{REFERENCES}

ADDINSOFT (2020) XLSTAT Basic, essential data analysis tools for Excel. URL: https://www.xlstat.com/en/solutions/basic (Accessed 23 November 2020).

AKCIL K and KOLDAS S (2006) Acid mine drainage (AMD): causes, treatment and case studies. J. Clean. Prod. 14 1139-1145. https://doi. org/10.1016/j.jclepro.2004.09.006

AMBANI AE and ANNEGARN H (2015) A reduction in mining and industrial effluents in the Blesbokspruit Ramsar wetland, South Africa: Has the quality of the surface water in the wetland improved? Water SA. 41 (5) 648-659. https://doi.org/10.4314/wsa. v41i5.08 
AUBÉ BC and LEE D (2015) The high density sludge (HDS) process and sulphate control. In: Proceedings of $10^{\text {th }}$ International Conference on Acid Rock Drainage and IMWA Conference 2015 - Agreeing on solutions for more sustainable mine water management. URL: https://imwa.info/docs/imwa_2015/IMWA2015_Aube_188.pdf (Accessed 30 March 2020).

AUBÉ BC and ZINCK JM (1999) Comparison of AMD treatment processes and their impact on sludge characteristics. In: Proceedings for Sudbury '99, Mining and the Environment II. 261-270. URL: http://www.envirobay.com/wp-content/uploads/2017/09/1999Lime-process-compare.pdf (Accessed 25 October 2020).

CLAASSEN M (2010) How much water do we have? In: A CSIR Perspective of water in South Africa - 2010. CSIR Report No. CSIR/ NRE/PW/IR/2011/0012/A. CSIR, Pretoria. 4-7.

COGHO VE (2012) Optimum Coal Mine: striving towards a 'zero effluent' mine. J. South. Afr. Inst. Min. Metall. 112 (2) 119-126.

COGHO VE and VAN NIEKERK AM (2009) Optimum coal mine water reclamation project. In: International Mine Water Conference, 19 - 23 October 2009, Pretoria, South Africa, 130-140. URL: https://www.imwa.info/docs/imwa_2009/IMWA2009_Cogho.pdf (Accessed 22 November 2020).

CREAMER M (2016) Minister launches long-term acid mine water solution. https://www.engineeringnews.co.za/article/water-ministerlaunches-long-term-acid-mine-drainage-solution-2016-05-18/rep_ id:4136 (Accessed 23 October 2020).

DWA (Department of Water Affairs, South Africa) (2012) Feasibility study for a long-term solution to address the acid mine drainage associated with the East, Central and West Rand Underground Mining Basins. Assessment of the Water Quality and Quality of the Witwatersrand Mine Voids. DWA Report No.: P RSA 000/00/16512/2. 20-26. DWA, Pretoria.

DWAF (Department of Water Affairs and Forestry, South Africa) (1996a) South African Water Quality Guidelines. Volume 7: Aquatic Ecosystems ( $\left.1^{\text {st }} \mathrm{edn}\right)$. Department of Water Affairs and Forestry, Pretoria.

DWAF (Department of Water Affairs and Forestry, South Africa) (1996b) South African Water Quality Guidelines. Volume 5: Agricultural Water Use: Livestock Watering ( $\left.2^{\text {nd }} e d n\right)$. Department of Water Affairs and Forestry, Pretoria.

DWAF (Department of Water Affairs and Forestry, South Africa) (1996c) South African Water Quality Guidelines. Volume 4: Agricultural Water Use: Irrigation ( $2^{\text {nd }}$ edn). Department of Water Affairs and Forestry, Pretoria.

DWS (Department of Water and Sanitation, South Africa) (2017) Eastern Basin Acid Mine Drainage Plant Launched. http://www.dwa. gov.za/Communications/PressReleases/2017/MS\%20-\%20Eastern\%20 Basin\%20Acid\%20Mine\%20Drainage\%20Plant\%20Launched.pdf (Accessed 19 January 2020).

DWS (Department of Water and Sanitation, South Africa) (2018) National Water and Sanitation Master Plan, Volume 1: Call to Action. Version 10.1, 31 October 2018. Dept of Water and Sanitation, Pretoria. 1-68.

DE WET L and SIDU S (2013) Water quality and compliance monitoring of treated underground and surface water at the Grootvlei Proprietary Mine and the Blesbokspruit wetland, Springs, South Africa. In: Reliable Mine Water Technology, International Mine Water Association, Annual Conference 2013. http://mwen.info/docs/ imwa_2013/IMWA2013_deWet_501.pdf (Accessed 30 March 2020).

DIGBY WELLS and ASSOCIATES (2012) Draft Scoping Report for the Immediate and Short Term Interventions for the Treatment of Acid Mine Drainage (AMD) in the Western, Central and Eastern Basins of the Witwatersrand Gold Fields. Prepared by Digby Wells and Associates, Johannesburg, South Africa, for Trans Caledon Tunnel Authority (TCTA), Centurion, Pretoria, South Africa, DEA Ref \# 12/1220/2403, Report No: BKS1310, 234, URL: https://www.yumpu. com/en/document/view/14035290/draft-scoping-report-sahra (Accessed 30 March 2020).

GCRO (Gauteng City-Region Observatory) (2019) Water Security Perspective for the Gauteng City-Region: Securing water for continued growth and well being. Report prepared for Gauteng Provincial Government. Document Version 10.8 - 28 October 2019. Gauteng City-Region Observatory, Johannesburg.
JOHNSON DB and HALLBERG KB (2005) Acid mine drainage remediation options: a review. Sci. Total Environ. 338 3-14. https:// doi.org/10.1016/j.scitotenv.2004.09.002

MCCARTHY TS (2011) The impact of acid mine drainage in South Africa. S. Afr. J. Sci. 107 (5-6) 1-7.

MCKAY T, NDLOPFU VW and AHMED AAQ (2018) The Blesbokspruit wetland, South Africa: A high altitude wetland under threat. Technical Report, Department of Environmental Sciences, University of South Africa. Report number: DES2018, URL: https:// www.researchgate.net/publication/326441349_The_Blesbokspruit_ wetland_South_Africa_A_high_altitude_wetland_under_threat. pdf (Accessed 15 January 2020). DOI: 10.13140/RG.2.2.12042.98244.

MILLIDINE KJ, MALCOLM IA, MCCARTNEY A, LAUGHTON R, GIBBINS CN and FRYER, RJ (2015) The influence of wind farm development on the hydrochemistry and ecology of an upland stream. Environ. Monit. Assess. 187 (8) 518. https://doi.org/10.1007/ s10661-015-4750-9.

MURDOCK DJ, FOX JRW and BENSLEY JG (1994) Treatment of acid mine drainage by the high density sludge process. In: International Land Reclamation and Mine Drainage Conference and the Third International Conference on the Abatement of Acidic Drainage, Pittsburgh. 241-249. https://doi.org/10.21000/JASMR94010241

OBERHOLSTER P (2010) The current status of water quality in South Africa - A Review. In: CSIR, A CSIR Perspective on Water in South Africa - 2010. CSIR Report No. CSIR/NRE/PW/IR/2011/0012/A, 8-17. CSIR, Pretoria.

OCHIENG GM, SEANEGO ES and NKWONTA OI (2010) Impacts of mining on water resources in South Africa: A review. Sci. Res. Essays. 5 (22) 3351-3357.

PILSON P, VAN RENSBURG HL and WILLIAMS CJ (2000) An economic and technical evaluation of regional treatment options for point source gold mine effluents entering the Vaal barrage catchment. WRC Report No. 800/1/2000. Water Research Commission, Pretoria. ISBN 186845535 I.

RAMSAR (2020) List of wetlands of international importance included in the Montreux Record. https://www.ramsar.org/sites/default/files/ documents/library/montreux_list_efs.pdf (Accessed 23 November 2020).

RAND WATER (2012) Standard sampling procedure. (Internal document) Document no. 3.3.1.10.1. Rand Water Analytical Services, Vereeniging.

RAND WATER (2020) Rand Water Analysis standards. URL: https:// www.randwater.co.za/WaterAndInfastructureManagement/Pages/ WaterAnalysis.aspx (Accessed 25 October 2020).

RSA (Republic of South Africa) (1998) National Water Act (Act No. 36 of 1998). Government Gazette 19182. Government Printer, Cape Town.

RESERVOIR (2018) Water resource information centre for the catchment forums that operate within the Vaal Barrage and Vaal Dam catchments of the Upper Vaal Water Management Area (WMA). http://www.reservoir.co.za/forums/vaalbarrage/blesbok_ forum/blesbok_home.htm (Accessed 18 February 2020).

RESERVOIR (2020) Water Quality Monitoring for the Eastern Basin AMD Plant quarterly report for October to December 2019. URL: http://www.reservoir.co.za/forums/vaalbarrage/blesbok_forum/bles bok_reports/current/TCTA_EB_Oct-Dec2019.pdf. (Accessed 1 April 2020)

ROYCHOUDHURY AN and STARKE MF (2006) Partitioning and mobility of trace metals in the Blesbokspruit: Impact assessment of dewatering of mine waters in the East Rand, South Africa. Appl. Geochem. 21 (6) 1044-1063. https://doi.org/10.1016/j. apgeochem.2006.02.024

SMITH EP (2014) BACI design. Wiley StatsRef: Statistics Reference Online. http://citeseerx.ist.psu.edu/viewdoc/download?doi=10.1.1.17 7.9612\&rep $=$ rep1\&type $=$ pdf (Accessed 18 October 2020).

SMITH EP, ORVOS DR. and CAIRNS JRJ (1993) Impact assessment using the before-after-control-impact (BACI) model: concerns and comments. Can. J. Fish. Aquat. Sci. 50 (3) 627-637. https://doi. org/10.1139/f93-072

SOLOMONS I (2017) Eastern basin AMD plant lauded for success achieved since coming on stream in June. https://www.mining weekly.com/print-version/eastern-basin-treatment-plant-integral-partof-r12bn-effort-to-combat-amd-2017-03-03 (Accessed 15 January 2020). 
THORIUS $\mathrm{T}$ (2004) The effect of Grootvlei mine water on the Blesbokspruit. MSc. dissertation, University of Johannesburg.

UNDERWOOD AJ (1994) On beyond BACI: sampling designs that might reliably detect environmental disturbances. Ecol. Appl. 4 (1) 3-15. https://doi.org/10.2307/1942110.

UNEP-AEWA (United Nations Environment Programme - Agreement on the Conservation of African-Eurasian Migratory Waterbirds) (2020) The Annotated Ramsar List of Wetlands of International Importance in South Africa. URL: https://www.unep-aewa.org/sites/ default/files/document/south_africa_nat_rep_appendix2_0.pdf (Accessed 24 October 2020).
VAN DER MERWE W and LEA I (2003) Towards sustainable mine water treatment at Grootvlei mine. In: $8^{\text {th }}$ International Congress on Mine Water and the Environment, 19-22 October 2003, Johannesburg. https://www.imwa.info/docs/imwa_2003/imwa_2003_025-036.pdf (Accessed 30 March 2020). 